Oliinyk O. I.,

Ph.D. in Law, Associate Professor, First Vice-Rector, Academy of the State Penitentiary Service, Chernihiv, Ukraine;

Korin A. V., officer of academic group 361,

Academy of the State Penitentiary Service, Chernihiv, Ukraine

\title{
EUROPEAN PUBLIC-LEGAL STANDARDS FOR LOCAL REFERENDUMS
}

The European standards in the field of functioning the institute of local selfgovernment are considered. The basic normative-legal acts of the Council of Europe that determine holding of local referendums are analyzed. The issue of determining the subject of a local referendum is considered. So, the subject of the local referendum are issues that are within the competence of local self-government and issues related to the revision of the boundaries of administrative and territorial units.

Key words: local referendum, people's initiative, democracy, people's power, local self-government.

Target setting. A local referendum, among other forms of direct democracy, is recognized as its most priority form, since it is in this case that the strong-willed expression of the main issues of local importance is exercised. From the practice of European countries, it seems that the referendum, as a manifestation of a people's initiative, is an effective mechanism of articulation of citizens' attitudes towards certain decisions of state authorities or targets of the local government. The institute for holding local referendums is enshrined in the Law of Ukraine "On Local Self-Government", but its practical implementation requires clarification and improvement through the borrowing of world experience.

Actual scientific researches and issues analysis. Some issues of the referendum institute were investigated by such scientists as V. F. Kotko, V. F. Pohorilko, V. N. Mamichev, V. L. Fedorenko, H. V. Sintsov, V. M. Shapoval and others. Despite the sufficiently active development of the problem of referendum in European law and the considerable number of papers in this field, there is still a lack of comprehensive comparative analysis on this issue, which makes the actuality of this scientific article. 
The purpose of the article is to make a comparative-legal analysis of the main legal acts that determine the holding of local referendums in European countries.

The statement of basic materials. The standards of the Council of Europe in the area of local democracy envisage the involvement of a wide range of individuals in solving issues of local importance. In accordance with the Convention on the Alienation of Foreigners in Public Life at the local level dated February 5, 1992, States parties undertake to bring about efforts to ensure the proper involvement of aliens living in a con on issues of local life (Article 4) [1].

In accordance with Recommendation No.R (96) "On Referendums and Public Initiatives at the Local Level", a consultative local referendum empowers foreigners and representatives of national minorities to participate in national elections. Enacting clause to the Recommendation contains warnings that practice of holding local referendums is connected with a number of potential risks (for example, "unwieldiness" of the process, risk of de-legitimation of representative character, local institutions, ability to make controversial decisions by adjacent bodies on issues of jointly interest) that are necessary to avoid. However, it is emphasized that the institutionalization of a local referendum of a national initiative within the framework of legal regulation is a way that guarantees the proper use of given institutions of direct democracy and reduces potential risks [2].

As it is noted in the Appendix to the Recommendation, in most Council of Europe member states, citizens have the opportunity to express their opinions through two institutes - a referendum and a people's initiative.

Recommendation Rec (2001) 19 of the Committee of Ministers of the Council of Europe "On Participation of Citizens in Local Public Life" emphasizes that local democracy is one of the cornerstones of democracy in Europe, and its strengthening is an act of strengthening. The Enacting clause to the Recommendation states that measures should be taken to involve citizens more directly in the management of local affairs, in order to preserve the effectiveness and efficacy of such management, with the following important principles in mind: 
- guaranteeing citizens the right to get access to clear, comprehensive information about the diverse issues that make up their local communities, and to make the right decisions about their most important decisions (paragraph 1 of Annex $I$ to the Recommendation);

- developing a general approach to the issue of citizens' education, linking as a mechanism of pre-eminent democracy, and also the form of direct learning in decision-making and in managing local affairs (paragraph 5 of Annex I to the Recommendation);

- ensuring that information is exchanged in and between countries on good practices related to local citizens' accountability (paragraph 8 of Annex I to the Recommendation) [3].

Legislative implementation of the right for a local referendum presupposes the existence, first of all, of a constitutional provision for holding referendums at the local level, consolidation of this norm in a special law on a local referendum and other normative and legal acts that specially regulate the procedure of holding referendum at local level. The procedure of holding local referendums itself is determined by the acts of local (regional) self-governing bodies [4]. The European Charter of Local Self-Government obliged the signatory states to enforce the basic legal norms that guarantee legal, administrative and financial autonomy of local communities and their bodies.

European standards in the sphere of functioning of the institute of local self-government consolidate the basic provisions at the level of the community of states, by means of norms of international law, and in the national (interstate). Thus, European standards for the functioning of local democracy establish rules that are recognized by most states. As, for example, the World Declaration of Local Government (1985), European Model Convention on the Basic Principles of Transfrontier Co-operation between Territorial Communities or Authorities (1980), European Declaration of Urban Rights (1992), European City Charter (1993), European Charter on Youth Participation in Municipal and Regional Life (1994). The adoption and implementation of these international normative and legal acts testifies to the existence of clearly defined international standards of local self-government, and to the status of administrative 
and territorial units not only in European, but also in European countries $[5$, p. 29].

Recent European Standards for Referendum Legislation Formulated in the Referendum Code of Good Practice Approved by the Council for Democratic Elections for its $19^{\text {th }}$ Session (2006) and Venice Commission at its $70^{\text {th }}$ plenary session (2007). The final approval of the guidelines for the organization and holding of referenda, set out in the Code, was facilitated by the adoption of Recommendation of the Parliamentary Assembly of the Council of Europe No.1821 "On the Code of Good Practice on Referendums" dated 23.11.2007 and the Declaration of the Committee of Ministers of the Council of Europe "On the Code of Good Practice on Referendums" dated 27.11.2008 [6, p. 43].

Currently, Ukraine is not a member of the European Union, but has been a member of the Council of Europe since 1995, and such membership imposes certain obligations on our state, including the provision of European standards of welcome. On 15 February 1996, the Committee of Ministers of the Council of Europe approved Recommendation No. R (96) 2 "On Referendums and Public Initiatives at the Local Level". The emphasis is on the fact that the institutionalization of the referendum and the people's initiative within the limits of legal regulation is the one that guarantees the proper use of these institutions of direct democracies and restrict potential risks. At the same time, Committee of Ministers of the Council of Europe expresses its concern that the referendum practice entails a number of risks, such as the risk of delegitimizing the representative body, the risk of significant referendum expenditures, The ideas embodied in the guideline of the aforementioned recommendation of the Committee of Ministers of the Council of Europe found their continuation in Parliamentary Assembly of the Council of Europe (hereinafter - PACE) Resolution No. 1121 "On Instruments for Citizens' Taking Part in Representative Democracy", 1997 [7].

The PACE notes that real democracy depends on the active involvement of all citizens in community affairs. However, in 1997, the PACE considered the referendum as an auxiliary instrument, giving priority to parliamentary democracy (paragraph 2 of resolution 
No. 1121, "On the Tools for the Participation of Citizens in Representative Democracy", 1997). In fact, from the very name of this resolution, it appears that it is largely devoted to instrumentation of the representative democracy. The risks which referendum institute contains are indicated. In particular, in paragraph 9 of the resolution analyzed, attention is drawn to the fact that the referendum may be used by the executive branch to strengthen its powers. Through correlation between direct and representative democracy, while PACE preferred the last one and mentioned that abuses connected with the referendums should not hide its real goal that was to ensure maintaining of representative democracy by wider citizens' attraction, because their participation consolidate the democracy and is an effective action against its "diseases" (paragraph 13 of the resolution). Thus, the referendum casts an optional, supportive role in the system of representative democracy. At the same time at the paragraph 12 of the analyzed PACE Resolution dated 1997, however, it emphasized that immediate consultations with the public make it possible to legitimize their own decisions and to make minority decisions heard.

In 2001, the Committee of Ministers of the Council of Europe adopted Recommendation No. 19 (2001) "On the Participation of Citizens in Local Public Life", as well as some of their points on referenda. The Committee of Ministers of the Council of Europe recommended, concerning referendums, that member states to adopt legislation in order to facilitate the initiation of referendum procedures and popular initiatives, to reduce the age requirement for young people to be able to take part in referendums, and to involve foreigners into local referendums. Already in the 2000s, the PACE's rhetoric on direct democracy gradually began to change. In PACE Resolution No. 1353 "On Strengthening Democratic Institutions as a Guarantee of Future Democracy" dated 2003 concludes that one of the major problems of modern democracy is the removal of citizens from political processes, a decrease in the level of trust in politicians and political parties, the elections, and also the need for a new reelection is expressed (paragraph 4). It is proposed to involve citizens more actively in the decision-making process, to pay attention to informing citizens in order to elicit their feelings of complicity in the decision-making process; to activate educational work in the spirit of 
democracy (paragraph 9 of PACE Resolution 1353 dated 2003). A proposal to widespread adoption of electronic voting (paragraph 10 of the said Resolution) and a call for the widest possible use of referendums and popular initiatives (paragraph 15). As we can see, in comparison with the recommendation dated 1997, the emphasis is gradually shifting from recognizing the referendum as an auxiliary tool for recognizing it as a self-governing instrument of direct democracy. Ultimately, a European Union law instrument that emphasized the importance of a referendum on the legal systems of European countries, became PACE Recommendation No. 1704 "Referendums: Towards a Good Practice in Europe" that was adopted in April 29, 2005 (at the $16^{\text {th }}$ meeting of PACE) [8].

This document finally broke the stereotypes concerning referendums; it is possible to say that it testifies to the successful promotion of the ideas of direct democracy in Europe. In Recommendation No. 1704, "Referenda: Towards a Good Practice in Europe", PACE stated that referendums form an ancient political tradition in a number of European countries, and in other countries, their implementation coincided with the transition to a pluralistic and representative democracy. The PACE considers referendums to be one of the tools that enable citizens to take part in decision-making. The PACE recognizes the important contribution that is made by organized civil society within the limits of "paticipatory democracy". PACE Recommendation number 1704 "Referenda: Towards a Good Practice in Europe" was adopted before ratification the European Union Constitutional Treaty. That is why PACE made assumption that it might be a great event because nearly 250 million citizens had to take part in all-European national referendums (in the aggregate of all national referendums), which was to become the largest national vote in the world for all time. As is known, the European Union Constitutional Treaty did not receive popular support [9, pp.187-188].

In this way, international and European standards reinforce the basic costs of direct democracy.

The legislation of European countries provides for the possibility of holding a regional, local or both referendum.

Legislative definition of the subject of a local referendum in European countries is done by two means: firstly, by identifying the 
issues that can be raised in a referendum; secondly, by identifying issues that cannot be cast in a referendum. The legislation of many countries does not impose restrictions on the issues that can be cast in a referendum (Czech Republic, Estonia, Finland, France, Lithuania, Malta, Poland) [10].

Conclusions. Thus, the institute of holding local referendums is fixed at the levels of international law, European normative-legal acts and domestic law.

The procedure for holding local referenda is governed by the legislation on local self-government or by local executive bodies. The subject of a local referendum contains issues that are within the competence of local self-government and issues related to the revision of the boundaries of administrative and territorial units. In the federal states, referendums are to be held in respect of the constitution (status) of the subjects of the federation. Like most national referendums, the majority of cases cannot be subject to fiscal issues. In all countries, local referenda do not address issues that fall within the national competence.

\section{References}

1. Council of Europe (1992), Convention on the Participation of Foreigners in Public Life at Local Level: Convention, International Document, available at: http://zakon4.rada.gov.ua/laws/show/994_318.

2. Council of Europe (1996), On Referendums and Popular Initiatives at Local Level: Recommendation, International Document.

3. Council of Europe (2001), On the Participation of Citizens in Local Public Life: Recommendation, International Document.

4. Council of Europe (1985), European Charter of Local SelfGovernment: Charter, International Document.

5. Shkabaro, V. M. (2013), "International and Legal Standards for Territorial Governance", Bulletin of the Alfred Nobel Dnipropetrovsk University, No. 1 (4), pp. 28-36.

6. Pavlenko, I. A., Makarov, H. V. and Tokar-Ostapenko, O. V. (2016), Legislative Regulation of the Local Referendum Institute in Ukraine, National Institute for Strategic Studies, Kyiv, pp. 42-50.

7. Council of Europe (1997), On instruments of citizens' participation in representative democracy: Resolution, available at: http://assembly.coe.int/Main.asp?link=/Documents/AdoptedText/ta97/ERES 1121.htm. 
8. Council of Europe (2005), Referendums: towards good practices in Europe: Recommendation, available

at: http://www.assembly.coe.int/nw/xml/XRef/Xref-XML2HTMLen.asp?fileid $=17329 \&$ lang $=\mathrm{e}$.

9. Bilan, S. V. (2017), "Referendum Regulation in European Law", Entrepreneurship, Economy and Law, No. 3, pp. 186-190.

10. Kovryzhenko, D. S. (ed.) (2007), Referendums in the European Union, FADA, LTD, Kyiv.

\section{ЄВРОПЕЙСЬКІ ПУБЛІЧНО-ПРАВОВІ СТАНДАРТИ МІСЦЕВИХ РЕФЕРЕНДУМІВ}

Розглянуто основні нормативно-правові акти Ради Свропи, щчо визначають проведення місиевих референдумів та встановлено, які новітні європейські стандарти законодавства про референдуми сформульовані в Кодексі належної практики щцодо референдумів. Проаналізовано основні стандарти вияву народної інічіативи під час вирішення питань місиевого значення. Розглянуто питання визначення предмета місцевого референдуму. Так, предметом, щзо виноситься на місцевий референдум, є питання, віднесені до компетениіі місиевого самоврядування, і питання, пов'язані з переглядом меж адміністративно-територіальних одиниць. В усіх крайнах на місцеві референдуми не виносяться питання, віднесені до загальнодержавної компетениії.

Наголошено, що реалізачія законодавчої реалізації права на місчевий референдум передбачає наявність конститучійного положення щчодо проведення референдумів на місцевому рівні, закріплення цієї норми у спеціальному законі про місцевий референдум та інших нормативно-правових актів, щзо спеціально регулюють проведення референдуму на місиевому рівні. Сам порядок проведення місчевих референдумів визначається актами органів місчевого (регіонального) самоврядування. Акиентовано увагу на інститучіоналізаџї референдуму як гарантії на належне використання прямої демократії.

Висвітлено позицію Комітету Міністрів Ради Свропи, яка полягає в тому, щьо практика референдумів містить у собі низку ризиків, а саме ризик делегітимізації представницького органу, ризик значних видатків на проведення референдумів, можливість прийняття суперечливих рішень із питань, щяо становлять спільний інтерес. Зазначено, щуо порядок проведення місчевих референдумів визначається актами органів місиевого (регіонального) самоврядування. Розглянуто європейські стандарти у сфері функиіонування інституту місцевого самоврядування, щз закріплюють основні положення на рівні співтовариства держав за допомогою норм міжнародного права, та в національному (внутрішньодержавному) законодавстві.

Ключові слова: місиевий референдум, народна інічіатива, демократія, народовладдя, місчеве самоврядування. 